\title{
Tabularia
}

TABULARIA Sources écrites des mondes normands médiévaux

\section{A charter of William the Conqueror and two of his} sons

Une charte de Guillaume le Conquérant et de deux de ses fils

\section{David Bates}

\section{OpenEdition}

\section{Journals}

Electronic version

URL: http://journals.openedition.org/tabularia/2500

DOI: $10.4000 /$ tabularia. 2500

ISSN: $1630-7364$

\section{Publisher:}

CRAHAM - Centre Michel de Boüard, Presses universitaires de Caen

\section{Electronic reference}

David Bates, "A charter of William the Conqueror and two of his sons », Tabularia [Online], Sources en ligne, Online since 08 July 2005, connection on 19 April 2019. URL : http://journals.openedition.org/ tabularia/2500 ; DOI : 10.4000/tabularia.2500 


\title{
A charter of William the Conqueror and two of his sons \\ Une charte de Guillaume le Conquérant et de deux de ses fils
}

\author{
David BATES \\ Director of the Institute of Historical Research, \\ University of London \\ David.Bates@sas.ac.uk
}

\begin{abstract}
:
I omitted a document from my edition of the charters of William the Conqueror on the grounds of arguments which had suggested that it was a charter of William Rufus. The signa are not all consistent with the document's date of 1084, but the charter, which is included in a pancarte destroyed in 1944, should be regarded as a charter of William I to which additions were made soon after his death. The document has some significance for the politics of 1088 and for relations between the Conqueror's sons.
\end{abstract}

Keywords: William I, King of the English and Duke of the Normans, Robert Curthose, Duke of the Normans, Henry I, King of the English and Duke of the Normans, Lessay, Abbey of, charter, pancarte.

\section{Résumé:}

Dans mon édition des chartes de Guillaume le Conquérant, j'avais laissé de côté un document, en me fondant sur des arguments suggérant qu'il s'agissait d'une charte de Guillaume le Roux. Les signa ne concordent pas entièrement avec la date du document (1084) mais la charte, qui est incluse dans une pancarte détruite en 1944, pourraît être considérée comme une charte de Guillaume Irer, qui reçut ensuite des additions après la mort de celui-ci. Ce document a une importance non négligeable pour ce qui concerne la situation politique en 1088 et les relations entre les fils de Guillaume le Conquérant.

Mots-clés: Guillaume I'r, roi des Anglais et duc des Normands, Robert Courteheuse, duc des Normands, Henri I ${ }^{e r}$, roi des Anglais et duc des Normands, abbaye de Lessay, charte, pancarte.

When I completed my edition of William the Conqueror's English, Norman and French charters, I deliberately omitted a document which Henry W. C. Davis had included in his calendar of the charters of William I and William II published in $1913^{1}$. I did so on the grounds that the charter was one of William II, rather

1. BAtes, David, Regesta Regum Anglo-Normannorum: The Acta of William I (1066-1087), Oxford, Clarendon Press, 1998, p. 9; DAVIS, Henry W. C., Regesta Regum Anglo-Normannorum, i, Oxford, 
than William I. In fact, the charter, a diploma recording a series of grants to the Norman abbey of Lessay, should have been included as a charter of William the Conqueror, but with the proviso that it contains additional material relating to events in Normandy in the year after his death. It provides a significant addition to our knowledge of the lives of two of his sons, his successor in Normandy, Robert Curthose, and his youngest son, the future Henry I. Its text is included in an appendix to this short article.

The text of the document is now known only from the defective nineteenthcentury edition in Gallia Christiana, from a copy made in 1876 but not published until 1910, and from a good early twentieth-century copy made by the chartiste Gaston de Beausse, whose papers were deposited in the Archives départementales du Calvados after his death during World War I. All three copies were made from a single sheet which was destroyed when the Archives départementales de la Manche at Saint-Lô were burnt in 1944. Taken together they show that the William I diploma and two subsequent notices and a colophon were written on the same parchment; the summary in the Inventaire sommaire of the série $\mathrm{H}$ of the Archives départementales de la Manche confirms this and provides a helpful guide to the diplomatic of the lost document ${ }^{2}$. John Horace Round included excerpts of the diploma, which he judged - probably incorrectly - to be an original, in his Calendar of Documents preserved in France, an opinion which Henry W. C. Davis repeated ${ }^{3}$.

The document once identified by Henry W. C. Davis as a William I diploma details grants made to Lessay in the year 1084 by Roger d'Aubigny. These were firstly the holding of Osmond the clerk of Feugères in the church of Saint-Samson of Geffosses and in Cricqueville-en-Bessin and Franqueville, with the agreement of Osmond's sons, one of whom became a monk at Lessay. Secondly Roger and his son Rualoc also gave the tithe of the toll of the fair of Saint-Christophe-d'Aubigny and of the market of Aubigny, land in Marchésieux and in the forest of Linverville, the latter with the exception of the tithe of the sixty acres held beforehand by SaintPaul of Cormery. Rainald d'Orval gave his portion of Marchésieux near to the monks' garden. Richard and William Bloet gave land in Créances. Each one of these grants is followed by a list of witnesses (testes) and the whole by a group of twenty signa, the first of whom is a king William (+ Signum Willelmi regis). The three

Clarendon Press, 1913, n 199. I am grateful to Pierre Bauduin for bringing this document to my attention and to him, Véronique Gazeau and Éric Van Torhoudt for their help with this article. I must also express my thanks to M. Gilles Désiré dit Gosset, Directeur des Archives départementales de la Manche for supplying helpful material and to Neil Stratford for showing me the edition of this charter by Sebastien Gosselin in his Ecole Nationale des Chartes thesis.

2. DOLBET, François, Inventaire sommaire des Archives départementales antérieures à 1790: Manche, Archives ecclésiastiques, série H ( $n^{\circ}$ 4301-8000), Saint-Lô, impr. Barbaroux, 1912, p. 43.

3. Round, John Horace, Calendar of Documents preserved in France illustrative of the History of Great Britain and Ireland, vol. i, A.D. 918-1206, London, Her's Majesty's Stationary office, 1899, $\mathrm{n}^{\circ} 920$. 
notices which follow the signa are firstly a record of a grant by William de Baudreville to Lessay of his part of the church of Varenguebec confirmed by his son Geoffrey who in turn added a further grant of his own, secondly, a gift by William Herbold, and thirdly, a colophon recording a final confirmation by the abbey's founder Eudo vicomte of the Cotentin and his wife in the presence of abbot Roger and the monks of Lessay in the chapter house of the abbey on Christmas Day. Gallia Christiana incorrectly dated this confirmation to 1095.

Davis' attribution of the diploma to William I was rejected in 1920 by Charles Wendell David, on the grounds that one of the signa is Bishop Odo of Bayeux, who was imprisoned by the Conqueror in late 1082 or early 1083, and could not therefore have subscribed a diploma of King William I which includes a dating-clause of $1084^{4}$. For this reason he preferred to assign the diploma to William II, and suggested that it could perhaps be dated to the year 1091 when the three brothers William Rufus, Robert Curthose and the future Henry I, all of whom David believed to be among the signa, were in western Normandy after the first two had besieged Henry in Le Mont Saint-Michel. This line of reasoning, appealing as it is, presents well-high insuperable problems which will be discussed later; in particular, at least one, and probably several, of the signa must date from earlier than 1091. It is also difficult to accept that William II should be the most prominent signum to a Norman diploma concerned entirely with Norman matters before the start of his protectorate of the duchy in 1096. In addition, although William the Conqueror's sons are known on occasion to confirm grants to religious houses in each other's territories, in all known cases this was done by twin confirmations, rather than all of them attesting a single document ${ }^{5}$. For these reasons alone, the text needs to be reconsidered and, given what we know of its form, assessed in the light of modern diplomatic criteria appropriate to a document written in typical pancarte form. The text is likely to be an edited compilation of a series of grants and the signa may well have been assembled over a period of time, or even merged from more than one earlier document ${ }^{6}$.

There are two basic possible ways in which the surviving pancarte might have been compiled, within which several further variables are possible. The first possibility

4. DAVID, Charles Wendell, Robert Curthose, Duke of Normandy, Cambridge, Mass., Harvard University Press, 1920, p. 36, note 86

5. In general, see BATES, David, "A Neglected English Charter of Robert Curthose, Duke of Normandy”, Bulletin of the Institute of Historical Research, lix (1986), p. 123-124; also ID., "Four Recently Rediscovered Norman Charters", Annales de Normandie, XLV (1995), p. 39-40, p. 46-47.

6. For two complementary magisterial studies of the subject, PARISSE, Michel, "Ecriture et récriture des chartes: les pancartes aux XI e ${ }^{e}$ XII ${ }^{e}$ siècles”, Bibliothèque de Ecole des Chartes, clv (1997), p. 247 265; ID., "Les pancartes. Études d'un type d'acte diplomatique" in Pancartes monastiques des XIe et XII ${ }^{e}$ siècles, Michel PARISSE, Pierre PÉGEOT and Benoit-Michel Tock (éd.), Turnhout, Brepols, 1998, p. 11-62. For Normandy, see especially MusseT, Lucien, Les actes de Guillaume le Conquérant et de la reine Mathilde pour les abbayes caennaises, Caen, MSAN, t. XXXVII, 1967, p. 25-35; BATES, David, "Les chartes de confirmation et pancartes normandes du règne de Guillaume le Conquérant", in Pancartes monastiques..., p. 95-109. 
is that the diploma may have been an original to which signa, perhaps with autograph crosses, were added at the moment of the document's first confirmation in 1084, with other signa, including Bishop Odo's, added later. In this case, the notices would have been additions made at different times in space in the middle of the parchment above the colophon which must date from before abbot Roger's death in $1094^{7}$; the confirmation by William de Baudreville's son Geoffrey, which took place in 1128, provides a terminus for its insertion, and in all likelihood for that of the other notices as well. The second is that the whole document was written by a single scribe after the confirmation of William de Baudreville's grant. In this case we are dealing with a single sheet, all of which was written after 1128, and which contained copies of all the documents ${ }^{8}$. The most plausible variable to these two basic possibilities is that the copy of the diploma was not written in 1084 but later after all the signa had been added, and that the lost single sheet contained distinct copies of five documents all made at different times before 1128. The loss of the crucial single sheet in 1944 makes it impossible now to decide between these possibilities. Whatever the case, however, it is of crucial significance that the abbey of Lessay is known from other evidence to have compiled documents in pancarte form and to have added signa to existing texts. The lengthy record of the earliest grants to the abbey accumulated its signa over a period of approximately half a century 9 .

The signa to the diploma contain several individuals either of primarily local significance or of wider significance, but with a power-base in the Cotentin. This is true of Roger d'Aubigny himself, Nigel vicomte of the Cotentin, Herbert d'Agneaux, Richard Bloet, Richard de Mary, Geoffrey de Say and in all probability of the otherwise unknown Odo Bardol, Gervase, Aubrey the chamberlain, William de Grimouville and Geoffrey Carbonel ${ }^{10}$. Roger d'Aubigny and his son Rualoc also appear as witnesses to the settlement of a plea held at Cherbourg on 27 December $1080^{11}$. Many of the other signa pose problems, however, because the descriptions are briefer than is normal in Norman charters of the second half of the eleventh century. Three, Maurice, Samson and Eudo, are nonetheless beyond any doubt identifiable with

7. For a hand-list of original pancartes and confirmation charters concerning Normandy before 1120, with ARTEM reference numbers, PARISSE, Michel, "Les pancartes...", p. 17 (Artem, nos 1983, 1996, 1991), p. 18-20 (Artem, ${ }^{\text {os }} 2337,2342,2348,2712,2846$ ), p. 25 (Artem, $n^{\circ} 4558$ ). For further comment on this type of document, POTTS, Cassandra, "The Early Norman Charters: a New Perspective on an Old Debate", in England in the Eleventh Century, ed. Carola HiCKS, ii Stamford, Paul Watkins, Harlaxton Medieval Studies, 1992, p. 34-35.

8. For an example of this type of procedure, Archives départementales de l'Orne, H 2156 (BATES, Regesta..., $\mathrm{n}^{\circ} 29$ (I) and (II)).

9. BATES, Regesta..., n 175 (I). This document was also destroyed in 1944. For a fac-similé, see Musée des Archives départementales, recueil de fac-similés héliographiques de documents tirés des Archives des Préfectures, Mairies et hospices, Paris, imprimerie nationale, 1878, planche XVIII.

10. For Herbert d'Agneaux, Richard de Mary and Geoffrey de Say, see BATES, Regesta..., $\mathrm{n}^{\text {os }}$ 26, 96, 215.

11. BATES, Regesta..., n 201. 
frequent members of William the Conqueror's entourage in the 1080s; the first two must be two of his chaplains - Maurice was also his chancellor - while the third must be Eudo, son of Hubert de Ryes, his steward ${ }^{12}$. Their presence together strongly suggests that the document is a diploma confirmed by William the Conqueror. Maurice's appearance is indeed conclusive proof of this since he became bishop of London in December 1085. A fourth signum, Adam, brother of Eudo, must be Adam fitz Hubert, Domesday tenant in several shires of Bishop Odo of Bayeux, and a Domesday survey commissioner in 1086 in the West Midlands ${ }^{13}$. His presence and Maurice's promotion to the bishopric of London are decisive evidence that William's signum was added to the diploma in either 1084 or 1085, since Maurice would surely have been styled episcopus after December 1085 and Adam was probably too busy in 1086 to visit Normandy. Roger de Courseulles-sur-Mer is an occasional witness of William the Conqueror's charters in the $1080 \mathrm{~s}^{14}$. Robert d'Ouilly was constable of Oxford castle, features otherwise only in William's English writs and charters, but was certainly prominent enough to suggest that he could have crossed the Channel in the king's entourage ${ }^{15}$.

Of the other signa, Bishop Odo of Bayeux, as already noted, is a chronological impossibility in either 1084 or 1085 . Robertus comes could be one of four individuals, William's son Robert Curthose, or any one of the counts of Eu, Mortain and Meulan. Since Norman charters of the period are exceptionally scrupulous in distinguishing between the last three, the probability favours Robert Curthose ${ }^{16}$. Yet he is most frequently styled filius regis in charters of William the Conqueror and went into his second exile very soon after 9 January $1084^{17}$. While Henricus filius regis is unquestionably the future Henry I, he is known to have been at the abbey of Abingdon at Easter 1084 and, while he does appear among the signa of diplomas for the abbey of Saint-Etienne of Caen which date from the 1080s, he was so obviously in England for much of the 1080s that it has been suggested that he was brought up there ${ }^{18}$. Abbot Rannulf could be either the abbot of Le Mont Saint-Michel of that name or the abbot of Lonlay. On grounds of geographical proximity, the

12. For Maurice, BATES, Regesta..., $\mathrm{n}^{\text {os }} 39,101,161,240,253,260,269$; Samson, ibidem, $\mathrm{n}^{\text {os }} 64$ (II), 64 (III), 162, 175 (I), 201, 253, 264, 265, 269; Eudo, ibidem, $\mathrm{n}^{\text {os }} 27,50,146,187,188,206,208,221,222$, $240,242,255,262,269$.

13. HeARne, Thomas, Hemingi Chartularium ecclesiae Wigornensis, 2 vols., Oxford, 1723, p. 287-88.

14. BATES, Regesta..., n ${ }^{\circ} 146$.

15. BATES, Regesta..., n ${ }^{\text {os }} 4,5,132,189,219,277,286,341,345$ (I).

16. There is no instance of ambiguity between the three counts in any Norman charter of William the Conqueror's reign. See the index entries in BATES, Regesta..., 1119-1120.

17. BATES, Regesta..., $\mathrm{n}^{\circ} 252$. The phrase Signum Roberti comitis occurs in Norman charters only in ibidem, $\mathrm{n}^{\mathrm{os}} 46,64$ (II), 142 (consul rather than comes), 229, 257, 283. One of these, $\mathrm{n}^{\circ} 229$, is a diploma for Rouen cathedral validated by Robert's signum and not by his father's.

18. HudSON, John, Historia ecclesie Abbendonensis: The History of the Church of Abingdon, Oxford, Clarendon Press, 2002, ii, p. 16-19. For the suggestion that he was brought up in England, BARLOW, Frank, William Rufus, new ed., New Haven and London, Yale University Press, 2000, p. 39-40; see 
former, who died on 19 December in either 1084 or 1085, with 1084 much the more probable, is the more likely, but the latter, who died on 31 December in a year after 1097 is not impossible ${ }^{19}$.

On balance there is sufficient evidence to assign this Lessay diploma to William the Conqueror, and to suggest that his signum and those of most of the others date from either 1084 or 1085 . Although our knowledge of William's itinerary in this period is rather weak, all the evidence suggests that he was in or around Normandy for the whole of 1084 and some of 1085 . He was there at an unknown place on 9 January 1084, at Rouen on 19 June 1084 and confirmed two other charters at Rouen during $1084^{20}$. He heard a plea between the abbey of Fécamp and Gulbert d'Auffay in Normandy in 1085, but must have spent a considerable part of the year in England preparing to counter an invasion from Denmark before proceeding to Gloucester for Christmas ${ }^{21}$. At some point during the two years he went into Maine to prosecute the siege of Sainte-Suzanne, before leaving the task to his military household ${ }^{22}$. It is possible to envisage a meeting between William's entourage and the local aristocracy from the vicinity of the abbey of Lessay either on the march south into Maine or on the return journey.

If this argument is accepted, then the signa of Robert Curthose and Bishop Odo must have been added at a later date. Two obvious times when this might have happened would be in late 1087 very soon after the Conqueror's death, or in the summer of 1088 soon after the failure of Robert's invasion of England and Bishop Odo's exile to Normandy ${ }^{23}$. At this time Odo was established as Robert's leading counsellor in Normandy and he had an interest in the gifts to Lessay because he was the founder's brother-in-law and the lord of one of the donors, Rainald d'Orval ${ }^{24}$. Although Robert's signum is most commonly accompanied by the description comes (or $d u x$ )

further HOLLISTER, Charles Warren, Henry I, London and New Haven, 2001, p. 36-37. For charters of Saint-Etienne of Caen, BATES, Regesta..., $\mathrm{n}^{\circ \mathrm{s}} 48,49$; for his appearances in English charters, ibidem, $\mathrm{n}^{\text {os }} 167,176,193,195,253,266$ (III). He does attest a confirmation for La Trinité of Caen in 1082 which looks to have been drawn up in Normandy, ibidem, $\mathrm{n}^{\text {os }} 59$ (I), 59 (II). N ${ }^{\text {os }} 60$ and 65 concern English properties and were probably confirmed in England.

19. For the death of Abbot Rannulf of Le Mont Saint-Michel, see now, GAZEAU, Véronique, Recherches sur l'histoire de la principauté normande (911-1204). II. Prosopographie des abbés bénédictins (911-1204), Dossier présenté devant l'Université de Paris I-Panthéon-Sorbonne en vue d'obtenir l'habilitation à diriger des recherches, 2002, p. 170. For Rannulf of Lonlay, ibidem, p. 145.

20. BATES, Regesta..., $\mathrm{n}^{\text {os }} 163,248$, 252; Historia ecclesie Abbendonensis, ii, p. 18-19.

21. BATES, Regesta..., n ${ }^{\circ} 145$. See further, ibidem, p. 82.

22. The Ecclesiastical History of Orderic Vitalis, ed. Marjorie ChIBNALL, 6 vols., Oxford, Clarendon Press, 1969-80, iv, p. 46-52.

23. For the chronology, BarLow, William Rufus, p. 85.

24. For Odo as Eudo Haldup's brother-in-law, BATES, David, Normandy before 1066, London and New York, Longman, 1982, p. 103; as Rainald d'Orval's lord, BouvRIs, Jean-Michel, "Aux origines du prieuré de Baupte (Manche): quatre actes inédits du XI ${ }^{e}$ siècle, dont deux actes du duc Robert CourteHeuse, extraits du cartulaire perdu de l'abbaye de Saint-Etienne de Caen", unpublished typescript of 
Normannnorum in his charters, there are occasions when he is simply Robertus comes $^{25}$. The future Henry I's signum may well also have been added after 1084-1085. Henry does sometimes appear in Robert's charters as filius regis and, in this case, it would be particularly appropriate and even logical for him to appear in 1088 because of his brother's grant to him of the Cotentin ${ }^{26}$. From the perspective of the monks of Lessay, it would surely also make sense to acquire further confirmation of grants recently made in William the Conqueror's time because of the changed political conditions affecting the Cotentin in 1088.

A final argument is that the charter apparently forms a pair with Robert's implementation of the grant of the mill of Vains to the abbey of Saint-Etienne of Caen, which Jean-Michel Bouvris has tentatively dated to immediately after the Conqueror's death; it too has the signa of Robert, Henry and Bishop Odo (and interestingly of Roger de Courseulles as well) and it and the Lessay diploma have the same formulations Robertus comes and Henricus filius regis ${ }^{27}$. These two charters may well indeed be a part of a larger and very interesting group which have been shown to illuminate the Conqueror's family's activities in Normandy in the aftermath of his death; one, dated 7 July 1088, is a restoration of property taken from the abbey of Fécamp by the Conqueror and another, less securely dated to 1087 or 1088, but quite probably from that time, is a grant by Robert made with Henry's agreement to the abbey of La Trinité of Caen where, as the charter says, their sister Cecilia was abbess ${ }^{28}$. Taken as whole, as Warren Hollister suggested, this set of charter evidence demonstrates further close collaborative relations between the Conqueror's eldest and youngest sons in the year after their father's death ${ }^{29}$.

If the disastrous loss in 1944 of the original pancarte renders all conclusions somewhat speculative, the restoration of this Lessay charter to William the Conqueror must illuminate both the regional politics of western Normandy in his last years and the inter-action between members of his family after his death. It adds to the corpus of the surviving charters of the Conqueror and it brings into focus aspects of the politics of the start of Robert Curthose's reign.

paper presented to the $42^{\text {nd }}$. Semaine d'Histoire du Droit normand at Mortain, 21-24 May 1981, $\mathrm{n}^{\circ}$ III. I am grateful to Jean-Michel Bouvris for a copy of this unpublished paper.

25. For examples of Robertus comes, HASKINS, Charles Homer, Norman Institutions, Cambridge, Harvard University Press (Mass.), 1918, Appendix F, nos 4 (a), 4 (b), 7; BouVRIS, Jean-Michel, "Aux origines du prieuré de Vains: une version inédite de la confirmation par le duc Robert Courte-Heuse d'une donation faite en 1087 par Guillaume le Conquérant à l'abbaye de Saint-Etienne de Caen”, Revue de l'Avranchin et du pays de Granville, lxiv (1987), p. 84-85; STAPLETON, Thomas, "Observations in disproof of the Pretended Marriage of William de Warren”, The Archaeological Journal, iii (1846), p. 26.

26. See also, BOUVRIs, “Aux origines du prieuré de Vains...”, p. 85; STAPLETON, “Observations...”, p. 26.

27. BOUVRIS, “Aux origines du prieuré de Vains...”, 77, p. 84-85.

28. Haskins, Appendix F, no 4 (a); STAPLeton, “Observations...”, p. 26 (concessu Henrici mei fratris).

29. HOLLister, Henry I, p. 48-50. 


\section{Appendix}

B. Caen, Arch. dép. Calvados F 5276. Copy by Gaston de Beausse from original or early twelfth-century pancarte destroyed in 1944 (Saint-Lô, Arch. dép. Manche, H 4603). In pencil at the end of the copy: 'hauteur $0.690 \mathrm{x}$ longeur $0.379 \mathrm{~m}$.'. Also 'Original parchemin sans trace scellement'. The ends of the lines of text on the original are indicated on the copy, suggesting that there were originally 38 lines plus the signa which follow after the record of the grants made in 1084 . The gaps in the copy indicate that the lower portions of the parchment were damaged.

Ptd.: Gallia Christiana in provincias ecclesiasticas distributa..., D. SAMARTHANUS et al, 16 vols. (Paris, 1715-1865), xi, instr. cols. 228-229 (from the lost original or early pancarte); DuBOSC, François, Une famille normande à travers mille ans. Histoire généalogique de la maison de Mary de Longueville (Coutances, 1910), pièces justificatives, p. ii, preuve $n^{\circ} 2$ (William I diploma only).

Cal.: Round, John Horace, Calendar of Documents preserved in France illustrative of the History of Great Britain and Ireland, vol. I, A.D. 918-1206, London, Her's Majesty's Stationary office, 1899, no 920 . (from the lost original or early pancarte); DAVIS, Henry W. C., Regesta Regum Anglo-Normannorum, i, Oxford, Clarendon Press, 1913, no 199 (from Round).

Note. The text below is based on ms. B, with variants in Gallia Christiana (GC) noted.

Anno ab incarnatione Domini M.L.XXXIIII, indictione VII Rogerus de Albineio ${ }^{30}$ dedit ecclesie $/{ }^{1}$ cenobii sancte Trinitatis que est in villa que appellatur Sancta Oportuna ${ }^{31}$, talem partem qualem Osmundus $/{ }^{2}$ clericus de Filgeris ${ }^{32}$ tenuit ab illo Rogero in ecclesia Sancti Sansonis de Givolli fossa ${ }^{33}$, et in maisnillo/ ${ }^{3}$ quod appellatur Cricca villa ${ }^{34}$ et in Franca villa ${ }^{35}$ scilicet totam illam terram quam predictus Osmundus $/{ }^{4}$ tenuit a supradicto Rogero in his maisnillis supranominatis, in terris laboratis et non laboratis, atque in $/{ }^{5}$ aquis et in silvis, annuentibus filiis ejusdem Osmundi, unus quorum nomine Robertus in eadem ecclesia monacus $/{ }^{6}$ effectus est. Idem Rogerus et Rualoc filius ejus dederunt eidem ecclesie pro animabus suis ac parentum $/{ }^{7}$ suorum decimam thelonei de feria Sancti Christofori ${ }^{36}$, et omnium

30. Aubigny, dép. Manche, cant. Périers.

31. Lessay, dép. Manche, chef-lieu de cant.

32. Feugères, dép. Manche, cant. Périers.

33. Geffosses, dép. Manche, cant. Lessay.

34. Criqueville-en-Bessin, dép. Calvados, cant. Isigny-sur-Mer.

35. Franqueville, dép. Calvados, cant. Isigny-sur-Mer, com. Fontenay Géfosse.

36. Saint-Christophe d'Aubigny, former commune joined in 1813 to Saint-Martin d'Aubigny, dép. Manche, cant. Périers. 
exituum ejusdem ferie, et decimam thelonei de foro $/{ }^{8}$ Albinei $^{37}$, et de omnibus exitibus qui ad idem forum pertinent, et in Marciseio ${ }^{38}$ unum ortolanum nomine Rogerum filium $/{ }^{9}$ Grentonis cum illa terra quam tenet, et in terra que fuit de foresta Liverville ${ }^{39} \mathrm{LX}$ acras terre, et IIII ${ }^{\text {or }}$ ex istis/ ${ }^{10}$ sunt de bosco, excepta decima istarum LX acrarum quam ante habebat Sanctus Paulus de Cormereio ${ }^{40}$. Harum rerum/11 testes sunt Eudo vicecomes et Rogerus de Broeio, ${ }^{41}$ et Ricardus de Cerencis ${ }^{42}$, et Ricardus de Landa ${ }^{43}$, et Robertus capellanus/ $/{ }^{12}$ Eudonis, et Rogerus de Landa et Rogerus Lambolt, et Rogerus del Pedrun ${ }^{44}$, et Rogerus dapifer, et Rannulfus filius Esturi, et ${ }^{13}$ Gaufridus presbiter Sancti Egidii ${ }^{45}$, et Radulfus Malcovenant, et Nigellus filius Osmundi de Filgeris ${ }^{46}$. Raginaldus etiam de Aurea valle ${ }^{47} /{ }^{14}$ dedit eidem ecclesie cenobii sancte Trinitatiis pro anima sua ac parentum suorum, suam partem de maresco quod est juxta gardinum $/{ }^{15}$ monacorum illius loci per talem divisionem qualem habent porprisam eidem monaci ad suum fossatum. Hujus rei sunt testes Eudo vicecomes, ${ }^{16}$ et Rogerus de Broeio ${ }^{48}$, et Ricardus de Cerencis ${ }^{49}$, et Robertus capellanus Eudonis, et Gaufridus del Rotor ${ }^{50}$, et Rannulfus de Balta ${ }^{51}$, Ricardus $/{ }^{17}$ etiam Bloet et Guillelmus Bloet dederunt eidem ecclesie cenobii sancte Trinitatis in villa que appellatur Criencis ${ }^{52}$ campum illum in quo/ $/{ }^{18}$ sedent grange eorundem monacorum, scilicet quicquid in illo campo habebant, pro animabus suis ac parentum suorum. Hujus rei sunt testes $/{ }^{19}$ Eudo vicecomes et Rogerus de Broeio ${ }^{53}$, et Ricardus de Cerencis ${ }^{54}$, et Robertus de Bricca villa ${ }^{55}$, Ricardus etiam Bloet dedit eidem ecclesie/20 [ceno]bii sancte Trinitatis pro anima sua ac parentum suorum, unam acram terre in sablone de villa

37. See above, note 30 .

38. Marchésieux, dép. Manche, cant. Périers.

39. The forest of Linverville. Linverville is part of Gouville-sur-Mer, dép. Manche, cant. Saint-Malo-dela-Lande.

40. Cormery, dép. Indre-et-Loire, cant. Montbazon.

41. Brouay, dép. Calvados, cant. Tilly-sur-Seulles.

42. Cérences, dép. Manche, cant. Bréhal.

43. Either La Lande de Lessay (around Lessay) or Saint-Malo-de-la-Lande, dép. Manche, chef-lieu de cant.

44. Saint-Aubin-du-Perron, dép. Manche, Saint-Sauveur-Lendelin. For this identification, see BouvRIS, Jean-Michel, "L’origine des prieurés de Marchésieux et de Boisroger, dépendances en Cotentin de l'abbaye de Cormery au diocèse de Tours" in Nédélèqueries. Recueil d'articles offert à Yves Nédélec, archiviste départemental de la Manche de 1954 à 1994, Saint-Lô, Société d'archéologie et d'histoire de la Manche, 1994, p. 107, n. 1.

45. Saint-Gilles, dép. Manche, cant. Marigny.

46. See above, note 32 .

47. Orval, dép. Manche, cant. Montmartin-sur-Mer.

48. See above, note 41 .

49. See above, note 42 .

50. Possibly Rots, dép. Calvados, cant. Tilly-sur-Seulles.

51. Baupte, dép. Manche, cant. Périers.

52. Créances, dép. Manche, cant. Lessay.

53. See above, note 41 .

54. See above, note 42 .

55. Bricqueville-la-Blouette, dép. Manche, cant. Coutances. 
Criencis ${ }^{56}$. Hujus rei sunt testes Eudo vicecomes, ${ }^{21}[\mathrm{~W}]$ illelmus de Bruer curte ${ }^{57}$, et Ricardus de Cerencis ${ }^{58}$, et Ricardus de Landa ${ }^{59}$, et Gaufridus frater ejus, et Robertus capellanus Eudonis, et Hugo filius Anslech./22

+ Signum Willelmi regis. + Signum Rogerii de Albineio ${ }^{60} .+$ Signum Odonis Baiocensis ${ }^{61}$ episcopi. + Signum Roberti comitis. + Signum Gervasii. + Signum Rannulfi abbatis. + Signum Herberti de Agneals ${ }^{62}$. + Signum Ricardi Bloet. + Signum Nielli vicecomitis. + Signum Sansonis. + Signum Mauricii. + Signum Eudonis. + Signum Adam fratri ejus. + Signum Henrici filii regis. + Signum Willelmi de Grimovilla $^{63}$. + Signum Gaufridi Carbonel. + S(ignum) Odonis Bardol. + S(ignum) Alberii camerari. + S(ignum) Rogeri de Corcella ${ }^{64}$. S(ignum) Ricardi de Meri ${ }^{65}$. + S(ignum) Gaufridi de Saio ${ }^{66}$. + Signum Roberti de Oillei ${ }^{67}$.

Willelmus etiam de Baudrevilla ${ }^{68}$ sancte Trinitatis ecclesie dedit pro anima sua omniumque parentum suorum partem ecclesie cum decima quam habebat in Wenrengebeko ${ }^{69} / 23$, et unam acram terre in eadem villa. Testes Humfridus sutor, Anschitillus Barbot, Radulphus Watel/24.

Hanc donationem Gaufridus filius eius anno ab incarnatione M.C.XX.VIII libenter concedens posuit super $/{ }^{25}$ altare sancte Trinitatis, et unam acram terre de suo insimul quam nobis in memorata villa pro sua suorumque anima dedit. Testes ex eius par ${ }^{26}$ te, Aszo presbiter frater ejus et Willelmus ${ }^{70}$ filius fratris sui Rogerii, nepos eorundem qui prefatam donationem vel concessionem concesserunt et cum eodem Gaufrido super $/{ }^{27}$ altare posuernt. Testes Willelmus .... ${ }^{71}$ Radulfus filius Adelais. Ex parte nostra Rogerius Colart, Malvielco us ${ }^{72}$, Willelmus de Inf... ${ }^{73}$, Maria filius Godelini/28, ${ }^{74}$, Humfridus filius Willelmi Galli/29.

56. See above, note 52 .

57. Probably La Brucourderie, dép. Manche, cant. Cerisy-la-Salle, com. Guehebert.

58. See above, note 41 .

59. See above, note 43 .

60. See above, note 30 .

61. Bayeux, dép. Calvados, chef-lieu d'arrondissement.

62. Agneaux, dép. Manche, cant. Saint-Lô-Ouest.

63. Grimouville, former parish joined to Regnéville, dép. Manche, cant. Saint-Martin-sur-Mer.

64. Courseulles-sur-Mer, dép. Calvados, cant. Creully.

65. Mary, a lost place-name whose name is preserved in the district known as 'La Rue Mary' in SaintCôme-du-Mont, dép. Manche, cant. Carentan.

66. Say, dép. Manche, cant. Quettehou, hamlet in com. Quettehou.

67. Ouilly-le-Basset, dép. Calvados, cant. Falaise-Nord, com. Pont-d'Ouilly.

68. Baudreville, dép. Manche, cant. La Haye-du-Puits.

69. Varenguebec, dép. Manche, cant. La Haye-du-Puits.

70. This word supplied from Gallia Christiana. B notes a blank in the ms.

71. B has a space after this word.

72. B has a space after this word.

73. B has a space after this word.

74. B notes a space in the $\mathrm{ms}$ at this point. 
[Noverint tam presentes quam f] uturi ${ }^{75}$ quod in tempore Rogerii abbatis ${ }^{76}$, Willelmus Herboldus pro anima sua et parentum $/{ }^{30}$ [suorum, dedit ecclesie sancta Trinitatis] ${ }^{77}$ Exaquii [et monachis] ${ }^{78}$ ibidem Deo servientibus Goscelinum patrem Pipini cum terra sua et quicquid in eadem terra $/{ }^{31}$ habebat, insuper et omnem substantiam suam dedit. Et Robertus frater ejus hanc donationem concessit. Et deinde Robertum monachum nostrum $/{ }^{32}$ de eadem terra saisiare fecerunt. Inde testes fuerunt Savredus presbiter de Wissel ${ }^{79}$, Anfredus presbiter, Robertus vicecomes de Wissel ${ }^{80}$, Radulfus Barbot $/{ }^{33}$, Herbertus prepositus, Rogerius Nibois. Et ex parte monachorum Herodes, Willelmus Blondus, Ricardus pistor, Willelmus pistor, Robertus cocus, Robertus Filiaster, Wazonis ${ }^{34}$.

Postea vero in die nativitatis Domini Eudone cum uxore sua in capitulo sancte Trinitatis Exaquii sedente petitione Rogerii abbatis et monachorum $/{ }^{35}$ suorum hoc supradictum donum concessit sicut ipse dudum in carta concesserat, quando ecclesiam fundaverat et ab omnibus servitiis sibi pertinentibus, illam ${ }^{36}$ terram liberam et absolutam esse precepit. Testes exinde fuerunt Ricardus de Cerenciis ${ }^{81}$, Gaufredus de Ferevilla ${ }^{82}$, Nigellus de Bricavilla ${ }^{83}$, Guillelmus de $/{ }^{37}$ Monasteriis ${ }^{84}$, Robertus capellanus de Milleriis ${ }^{85} / 38$.

\footnotetext{
75. B notes a space in the $\mathrm{ms}$ at this point. I have inserted a likely reading.

76. Roger, abbot of Lessay, died 29 June 1094.

77. B notes a space in the $\mathrm{ms}$ at this point. I have inserted a likely reading.

78. B notes a space in the $\mathrm{ms}$ at this point. I have inserted a likely reading.

79. Le Vicel, dép. Manche, cant. Quettehou.

80. See above note 79 .

81. See above note 42 .

82. Fierville, dép. Manche, hamlet in cant. and com. Lessay.

83. Bricqueville-la-Blouette, dép. Manche, cant. Coutances.

84. Possibly Les Moitiers-en-Bauptois, dép. Manche, cant. Saint-Sauveur-le-Vicomte.

85. Millières, dép. Manche, cant. Lessay.
} 